\title{
THE ABORIGINAL PEOPLES ACT 1954 AND THE RECOGNITION OF ORANG ASLI LAND RIGHTS
}

\section{Izawati Wook}

Senior Lecturer, Fact. Of Syariah and Law, Universiti Sains Islam Malaysia, Negeri Sembilan, Malaysia. Email: izawati@usim.edu.my

\begin{abstract}
The prevailing view about the Orang Asli's occupation of land and access to forest resources are that they are 'privileges' extended by the states or at the governments' discretion. It is widely believed that the Orang Asli live on the State land as tenant-at-will. This paper proposes to examine the position of the Aboriginal Peoples Act 1954 (Act 153) (the APA) and trace its historical background. It takes both historical and doctrinal approaches in the legal research methodology. Situated within this historical background, the principle that developed from it and the position of the laws, the paper argues that under the principle of respect to the rights of the existing inhabitants, the law recognizes the rights of the Orang Asli to their land and resources that arose from their custom and practice. The APA establishes a framework to recognize and protect these rights. There is no legal basis for the perception that the Orang Asli live on the State land on the benevolence of the State.
\end{abstract}

Keywords: Legal history; Aboriginal Peoples Act 1954; Indigenous peoples; Orang Asli; Peninsular Malaysia.

\section{Introduction}

The Orang Asli are minority groups and indigenous peoples of Peninsula Malaysia. The term 'Orang Asli' is a Malay phrase for 'original peoples' or 'first peoples'. They represent 18 different groups of aboriginal and minority peoples. Each of the groups has its own language, culture, economy, religion, social organization and physical characteristics. ${ }^{1}$ They number 178,197 as at 2010 and constitute less than $0.5 \%$ of the Malaysian population. $^{2}$

There has been considerable conflict between the Orang Asli communities and state governments over their continued customary rights in land and forests. The indigenous minorities assert, on the basis of their traditional and customary laws, a right to occupy land and use of forest resources that they have enjoyed for generations. On the other hand, the prevailing view about the Orang Asli's occupation of land and access to forest resources are that they are 'privileges' extended by the states or at the governments' discretion. Without grant of title, it is widely believed that the Orang Asli live on State land as tenant-at-will, upon absolute discretion of the state authorities.

These traditional rights are partly recognized by Malaysian common law. Under the common law, their customary laws, custom and practices are the source of the rights that define the nature of aboriginal land rights ie the scope and extent of the rights and interests. ${ }^{3}$ Continuous occupation and control of land may also evidence the land rights ${ }^{4}$ which may also include the right to forage and hunt the resources in the area. ${ }^{5}$ The court rulings

\footnotetext{
${ }^{1}$ For a detailed account on the population, see, eg, Iskandar Carey, Orang Asli: The Aboriginal Tribes of Peninsular Malaysia (Oxford University Press, 1976); Robert Knox Dentan et al, Malaysia and the Original People: A Case Study of the Impact of Development on Indigenous Peoples (Allyn and Bacon, 1997).

${ }^{2}$ Human Rights Commission of Malaysia (Suhakam), 'Report of the National Inquiry into the Land Rights of Indigenous Peoples' (Suhakam, 2013) <http://www.suhakam.org.my/documents/10124/1326477/SUHAKAM+BI+FINAL.CD.pdf http://sarawakreport.org/suhakam/suhakam-chapter8.html>, 16.

${ }^{3}$ Adong bin Kuwau v Kerajaan Negeri Johor [1997] 1 MLJ 418 ('Adong 1'); Kerajaan Negeri Johor v Adong bin Kuwau [1998] 2 MLJ 158 ('Adong 2'); Nor Anak Nyawai v Borneo Pulp Plantation Sdn Bhd [2001] 6 MLJ 241; Sagong bin Tasi v Kerajaan Negeri Selangor [2002] 2 MLJ 591 ( 'Sagong 1'); affirmed by Federal Court in Superintendent of Lands \& Surveys Miri Division v Madeli bin Salleh [2008] 2 MLJ 677 (Madeli'). See also a recent case, Mohamad bin Nohing v Pejabat Tanah dan Galian Negeri Pahang [2013] MLJU 291 ('Nohing').

${ }^{4}$ Madeli [2008] 2 MLJ 677.
} 
Izawati Wook, 'The Aboriginal Peoples Act 1954 and the Recognition of Orang Asli Land Rights', ISSN 2229984X', UUMJLS, vol. 6, no. 1, 2015, pp. 063-083.

are supported by: the common law principle of respect to the right of the existing inhabitants under their custom, which acknowledges the use and occupation of land by indigenous peoples; the statutory right provided under Aboriginal Peoples Act 1954 and the constitutional provisions on the special position of the Orang Asli. ${ }^{6}$

Statute law is generally silent on matter of Orang Asli land right although the communities' special position is acknowledged and some access to forests is recognized. ${ }^{7}$ Under the state land codes, state authorities have wide powers to dispose of title to state land. Title to state land cannot be acquired by adverse possession, unlawful occupation or occupation under any licence. However there is a saving clause in the codes preserving customary tenures. ${ }^{8}$ This may include the customary rights of the Orang Asli but were not interpreted as extending to any land of the Orang Asli until the case of Sagong Tasi ${ }^{9}$ in 2002. The interpretation of the law and its implementation in practice had jeopardized the land tenure by the Orang Asli. The state forestry laws enforce state control of forests and have led to the creation of forest reserves which further restrict the access of the Orang Asli to their resources. ${ }^{10}$

This lack of formal recognition results in insecurity. Without title, the Orang Asli are considered as occupying land at the discretion of the state. This perspective continues despite of the common law position on the Orang Asli land rights. The result is continuing encroachment on their customary lands by outsiders for logging, commercial farming and infrastructure development. ${ }^{11}$

This paper examines the position of the land and resource rights of the Orang Asli in its historical context and perception, the development of law in general and the specific legislation that deals with the aboriginal affairs, the Aboriginal Peoples Act 1954 (Act 153) (the APA). Based on historical and doctrinal approaches, the paper seeks to argue that the law acknowledges the land and resource rights of the Orang Asli. It establishes a framework to recognize and protect these rights particularly through the APA. It entrusts both the Federal Government and State Authorities as the protector of these rights.

The paper traces the historical background of the development of the legal system in Malaysia that laid down a basic principle of respect to the existing rights of people. On this historical context, the paper suggests that the position of the land rights of the Orang Asli must be situated within this principle. This principle has also dictated the position of other legislation that affects the land and resource rights of the Orang Asli. But the later development of the laws has been affected by several factors that affect the recognition of the Orang Asli land

\footnotetext{
${ }^{5}$ Nohing Application for Judicial Review No 24-4-2007 (18 March 2013) (High Court of Malaya, Temerloh) (Unreported)

${ }^{6}$ Adong 1 [1998] 2 MLJ 158; Kerajaan Negeri Selangor v Sagong bin Tasi [2005] 6 MLJ 289 ('Sagong 2').

${ }^{7}$ See below: Part 4.5 .

${ }^{8}$ National Land Code (Malaysia) s 4(2)(a): 'Except in so far as it is expressly provided to the contrary, nothing in this Act shall affect the provisions of any law for the time being in force relating to customary tenure'; $\mathrm{s}$ 40: 'There is and shall be vested solely in the State Authority the entire property in (a) all State land within the territories of the State; (b) all minerals and rock material within or upon any land in the State the rights to which have not been specifically disposed of by the State Authority'; S 41 provides for power of disposal and reversion to state authorities: 'No title to State land shall be acquired by possession, unlawful occupation or occupation under any licence for any period whatsoever'.

${ }^{9}$ Sagong 1 [2002] 2 MLJ 591

${ }^{10}$ Human Rights Commission of Malaysia (Suhakam), above n 2; Jeyamalar Kathirithamby-Wells, Nature and Nation: Forests and Development in Peninsular Malaysia (NIAS Press, 2005), 125-133; Shaik Mohd. Noor Alam Hussain, 'Legal Aspects of Forestry' (1983) 1 Current Law Journal 64.

${ }^{11}$ See eg, Signe Howell, '"We People Belong in the Forest": Chewong Re-creations of Uniqueness and Separateness' in Geoffrey Benjamin and Cynthia Chou (eds), Tribal Communities in the Malay World (Institute of South East Asian Studies, 2002) 254; Human Rights Commission of Malaysia (Suhakam), above n 2. Eg of recent news reports include: 'Temiar Tribe in Dire Straits', The Sun Daily 13 February 2013, 4 <http://www.thesun-epaper.com/wed/13022013/files/assets/basichtml/page4.html>; Nigel Aw, 'Mega Plantations Gobble Up Kelantan Orang Asli Land', Malaysiakini 28 December 2012; Mustafa K. Anuar, 'The Temiar Blockade, Arrests in Gua Musang', The Malaysian Insider 30 January 2012 <http://www.themalaysianinsider.com/litee/sideviews/article/the-temiar-blockade-arrests-in-gua-musang-mustafa-k.anuar/>; Zulaikha Zulkifli, 'Hundreds of Orang Asli Deliver Memo to Pahang MB', Malaysiakini 17 October 2012 <http://www.malaysiakini.com/news/211999>; Hasan Mat Nor et al, 'Mengapa kami jadi begini? Konflik masyarakat Orang Seletar dan Pembangunan Iskandar, Johor Bahru, Malaysia (Why do we become like this? The conflict of Orang Seletar communities and Iskandar Development, Johor Bahri Malaysia)' (2009) 5(2) Malaysian Journal of Society and Space 16; n.a., 'Orang Asli protest loss of land', The Star 20 June 2010; Laven Woon, 'Orang Asli Land Still under Threat', Free Malaysia Today 28 September 2012 <http://www.freemalaysiatoday.com/category/nation/2012/09/28/orang-asli-land-stillunder-threat/>; Orang Asli ordered to vacate land get consent stay', Sunday Daily 14 August 2012 $<$ http://www.thesundaily.my/node/111762>.
} 
Izawati Wook, 'The Aboriginal Peoples Act 1954 and the Recognition of Orang Asli Land Rights', ISSN 2229984X', UUMJLS, vol. 6, no. 1, 2015, pp. 063-083.

rights. Therefore there is no legal basis for the perception that the Orang Asli live on State land on the benevolence of the State.

The argument is framed based on three aspects.

First, situated within its context and history of the development of laws and policies in the country, the longstanding practice and development of the laws developed into principle of respect to the rights of the existing inhabitants. This established principle holds that the laws acknowledge the rights and interests that derived from the custom and usage of the people if exist. The laws could not be taken to override these interests unless specifically stated so. On the principle of equality, which is also the basic principle of law, the principle of respect to the rights of people is not only applicable to the Malays, but also the Orang Asli who are known to be the first people of the peninsula.

Second, the content of the Act itself establishes a framework to recognize and protect the land and resource rights of the aborigines.

Third, the position of other statute suggests that the law acknowledges the interests that the Orang Asli have in land, although, it has gradually been eroded.

\section{The Historical Background: The Principle of Respect to the Rights of the Existing Inhabitants}

In the history of the development of laws and policies in the country, the rights and interests of people that arose from their customary laws were given recognition. This is evident by the practice of treaty making and regard for the local customs and religions, as well as the rights and interests of the local inhabitants both in the development and administration of laws. Prior to British colonization period in the Malay Peninsula by late $17^{\text {th }}$ century, the possession of land by the aboriginal groups was also not denied.

\section{Relationship between the Malays and the Orang Asli}

Orang Asli communities were regarded as distinct communities from the Malays, having autonomy and control over their own territories with their own customs and traditions regulating their own affairs. Although various accounts suggested that the Malays often regarded themselves as superior to the aborigines, the autonomy and control of the aborigines over their own territories were not denied. The aborigines regarded themselves as the original inhabitants of the Malay Peninsula and independent of the Malay rulers. ${ }^{12}$ Historical accounts indicate

\footnotetext{
${ }^{12}$ Nicholas, Colin, The Orang Asli and the Contest for Resources (International Work Group for Indigenous Affairs, 2000), 74-6 citing various works including: Andaya, Barbara Watson and Andaya Y Andaya, A History of Malaysia (Macmillan Education, 1982) 49-50: suggest that when the Malay newcomers arrived with an established system and political ranks, there were already Orang Asli groups in the Malacca region. When Parameswara, the founder of the Malacca Empire, arrived in Malacca, there were populations including the Orang Asli living in the region. Parameswara tightened his position by building relationships with the communities, enjoining them in the political establishment or through inter-marriage; Mikhulo-Maclay, N Von, 'Ethnological Excursions in the Malay Peninsula: Nov. 1874 to Oct. 1875: (Preliminary Communication)' (1878) 2 (Dec) Journal of the Straits Branch of the Royal Asiatic Society, 203-221, 215: recorded that 'the Orang Sakai and the Orang Semang consider themselves the original inhabitants and independent of the Malay Rajahs, and so they are in fact in their woods'; Noone, H D, 'Report on the Settlements and Welfare of the Ple-Temiar Senoi of the Perak-Kelantan Watershed' (1936) 19(1) Journal of the Federated Malay States Museums 1, 61-2: observed that the Temiar people prior to the intervention of British rule 'pursued the independent existence of a hill people on the Main Range'; AH Hill, The Hikayat Abdullah: The Autobiography of Abdullah bin Kadir (1797-1854) (An Annotated Translation) Second Impression, (Oxford University Press, 1985) 260-1: the Orang Asli tribes in Naning held dominion over Naning in Malacca since early Portuguese control of Malacca. It also relates that in 1642, a representative from the Biduanda tribes was appointed as ruler in Naning during the Dutch rule in Malacca; Wilkinson, RJ 'Malay Law in Papers on Malay Subjects, Part I, 1-45', 1908 reprinted in MB Hooker (ed), Readings in Malay Adat Laws (Singapore University Press, 1970): the Biduanda tribes were also regarded as having control of their territories; Newbold, TJ, Political and Statistical Account of the British
} 
Izawati Wook, 'The Aboriginal Peoples Act 1954 and the Recognition of Orang Asli Land Rights', ISSN 2229984X', UUMJLS, vol. 6, no. 1, 2015, pp. 063-083.

that they had their own political establishments with their own leaders and legal systems. Their leaders, who were the reference point for all customary matters, were regarded as having the same standing as that of the Malay rulers. ${ }^{13}$ Many had important political alliances with the Malay sovereigns. Some played important roles in the defence of some Malay rulers. Traditional stories suggest that marriage with the Orang Asli legitimised Malay connection with, and political power over, their territories. ${ }^{14}$ The Orang Asli also had trading relationships with the Malays particularly in the supply of forest resources in exchange for other needs. ${ }^{15}$ Adat perpatih [customary law] in Negeri Sembilan specifically recognized that the aborigines owned the forests and its resources and required Malays to respect their needs and interests. ${ }^{16}$

\section{Treaty Making and Its Origin}

In the Malay states, treaties governed the relationship between British and the local people. Some of the treaties include: Treaty with the East Indian Company 1825, Cession of Dinding 1826; Treaty with the East India Company 1826; and Treaty of Pangkor (in Perak); Treaty of 1889 (in Negeri Sembilan); the unsigned Treaty of 1786; Second Treaty of 1791; Third Treaty of 1800 (in Kedah - relating to cession of Penang); Treaty with Great Britain 1910 (Kelantan); Treaty of 1885; and Treaty of 1914 (Amendment of 1885 Treaty) (Johor). These treaties defined the relationship between the British and the local peoples specifically on commercial business and the manner of states administration.

In Selangor, where there was no treaty, Roland Braddell wrote that an interchange of letters, a proclamation, and the reception of officers were to assist the Sultan to 'govern his country and to protect the lives and property of dwellers in, and traders to, Selangor'. ${ }^{17}$ The protection of lives and property was accepted as the very reason for the reception of the British officials and their power in the Malay States.

Treaty making indicates regard to the political autonomy of the indigenous peoples on their own land and laws. Historically the practice of treaty and agreement was adopted as early as the beginning of the British Empire in India. In North America, the Royal Proclamation of 1763 recognized the political autonomy of the Native Americans allied with the Crown as well as control of their lands and resources. ${ }^{18}$ The treaty forbade direct purchase of native land by settlers under the principle that the Crown could be the sole source of title to land for settlers. Land from Native American territories could only be acquired by government officials in public treaty processes rather than taken by force or usurpation. The practice was intended to inhibit the dispossession of the inhabitants from their land by force as practiced by Spanish conquistadores in the Spanish expansion which they denounced. ${ }^{19}$ Following the Royal Proclamation, Treaty of Niagara 1764 was negotiated with representatives from at least 22 Indian Nations. The principles agreed to include the recognition of Indian governance, free

Settlements in the Straits of Malacca 2 Volumes 1839, (Oxford University Press, 1971 - reprint), Vol II 117-126: relates that Jakuns and Biduandas were the respected leaders in Malacca.

${ }^{13}$ Ibid, 75 citing Endang, an Orang Asli leader in Pahang with reference to an oral tradition of Batin Simpok and Batin Simpai in Pahang.

${ }^{14}$ Eg of the legends: Haji Buyong Adil, Sejarah Negeri Sembilan (Dewan Bahasa dan Pustaka, 1981), 4 on inter-marriage of a Sultan of Johor with a Biduanda from Negeri Sembilan; Maxwell, WE, 'The History of Perak from Native Sources' (1882) 8 Journal of the Straits Branch of the Royal Asiatic Society 93-125 on the legend of the White Semang in Perak, a member of whom married a Nakhoda Kasim from Johor and founded the Perak Sultanate; Gullick, JM, Indigenous Political Systems of Western Malaya (1965) 17 (The Athlone Press, 1965), 39 on how aspiring heirs in Negeri Sembilan had to resort to claiming Orang Asli (matrilineal) ancestry in order to be eligible for hereditary positions. This was achieved by claiming that the founders of their families were the sons of Orang Asli ancestresses married to Malaccan noblemen. The works are cited in ibid, 75 .

15 John D Leary, 'Orang Asli Contacts with the Malays, Portuguese and Dutch in Peninsular Malaya from 1400 to 1700 ' (1994) 18(2) Asian Studies Review 89, 98.

${ }^{16}$ Hooker, MB, Readings in Malay Adat Laws (Singapore University Press, 1970), 25-6 cited in Nicholas, above n 12, 74.

${ }_{17}$ Roland Braddell, The Legal Status of the Malay States (MPH, 1931), 6, the extract was reproduced in Salleh Buang, 'Malay Customary Tenure: A Brief Historical Survey' in Ahmad Ibrahim and Judith Sihombing (eds), The Centenary of the Torrens System in Malaysia (Malayan Law Journal, 1989) 171,151.

${ }^{18}$ James W. Zion and Robert Yazzie, 'Indigenous Law in the Wake of Conquest' (1997) 20 Boston College International Comparative Law 55, 65.

${ }^{19}$ P.G. McHugh, Aboriginal Title: The Modern Jurisprudence of Tribal Land Rights (Oxford University Press, 2011), 26. 
Izawati Wook, 'The Aboriginal Peoples Act 1954 and the Recognition of Orang Asli Land Rights', ISSN 2229984X', UUMJLS, vol. 6, no. 1, 2015, pp. 063-083.

trade, open migration, respect for Indian land holdings, affirmation of Indian permission and consents on treaty matters, and respect for hunting and fishing rights. ${ }^{20}$

Treaty making became the official policy of the British crown in acquiring land from Indian nations in North America, not only for just law and morality but integral strategy for pragmatic reasons such as business expansion. The practice which recognized the political autonomy of the indigenous peoples developed into a body of political practices and common law. ${ }^{21}$ Although there is disagreement among scholars on whether the Royal Proclamation 1763 recognized or undermined tribal sovereignty, the proclamation established an important precedent that the indigenous inhabitants had rights to the unceded lands and those rights could be surrendered only to the Crown or its duly appointed agents in public council. ${ }^{22}$ It recognized that lands possessed by Indians throughout British territories in America were reserved for their exclusive use, unless previously ceded to the Crown. ${ }^{23}$

A treaty evidenced the recognition of the indigenous peoples as legal and political entities with rights to sovereignty and political authority over their respective lands. It defined the relationship between the British crown and the indigenous peoples. The terms of treaties certainly varied depending on the circumstances of particular territories but the common principle is that the indigenous peoples did not lose their right to land and their resources by being subjected to British sovereignty and they maintained a right to some form of political representation in relation to the powers of the new state. ${ }^{24}$

The North American experience heavily influenced the development of legal principle and policy in the independent United States of America (the US), ${ }^{25}$ Canada and other territories. In the US, it developed into laws protecting the sovereignty of Native American nations and imposing fiduciary obligations on the US government protecting their property. ${ }^{26}$ In Canada the treaty making practice led to the recognition of First Nation's property rights at the common law which also received constitutional protection. ${ }^{27}$ Treaty-making spread to other part of the world including New Zealand and some parts of British Columbia. It was also used in Africa and Asia, particularly in India and the Malay States. ${ }^{28}$

The state practices respecting the rights of existing inhabitants laid the basis for the development of the doctrine of aboriginal title as it is endorsed by courts in common law jurisdictions. It was also acknowledged by the International Court of Justice in $1975 .{ }^{29}$ The British practice is not unique as the same is also seen in the pattern of treaty making between other European powers and indigenous peoples in the period of colonization. ${ }^{30}$ Despite many flaws and breaches in practice, this tradition has become an important source for the legal order in

\footnotetext{
${ }^{20}$ Zion and Yazzie, above $\mathrm{n} 18$.

${ }^{21}$ Ibid, 65 .

${ }^{22}$ Colin G. Calloway, The Scratch of a Pen: 1763 and the Transformation of North America (Oxford University Press, 2006), 96.

${ }^{23}$ Brian Slattery, 'The Hidden Constitution: Aboriginal Rights in Canada' (1984) 32 American Journal of Comparative Law $361,371$.

${ }^{24}$ Tom G. Svensson, 'On Customary Law: Inquiry into an Indigenous Rights Issue' (2003) 20(2) Borialia, Acta 85, 95-119.

${ }^{25}$ In 1783, the Great Britain ceded the territory to the United States through the Treaty of Paris: Zion and Yazzie, above $\mathrm{n}$ $18,66-67$.

${ }^{26}$ Ibid.

${ }^{27}$ Slattery, above n 23, 366-372. The Royal Proclamation of 1763 is mentioned in s 25 of the Canadian Charter of Rights and Freedom. S 25 provides:

The guarantee in this Charter of certain rights and freedoms shall not be construed as to abrogate or derogate from any aboriginal, treaty or other rights or freedoms that pertain to the aboriginal peoples of Canada including: (a) any rights or freedoms that have been recognized by the Royal Proclamation of October 7, 1763; and (b) any rights or freedoms that now exist by way of land claims agreements or may be so acquired.

${ }^{28}$ A few treaties were concluded on Victoria Island but the mainland was not covered by foundation of treaty. See McHugh, above $\mathrm{n} 19,30$

${ }^{29}$ Western Sahara: Advisory Opinion of 16 October 1975, 975 ICJ 12, 37039 (1975). The majority state that:

Whatever differences of opinion there may have been among jurists, the State practice of the relevant period indicates that territories inhabited by tribes or peoples having a social and political organization were not regarded as terra nullius. It shows that in the case of such territories the acquisition of sovereignty was not generally considered as effected unilaterally through 'occupation' of terra nullius by original title but through agreements concluded with local rulers.
}

${ }^{30}$ SJ Anaya, Indigenous Peoples in International Law (Oxford University Press, Second ed, 2004), 19. 
Izawati Wook, 'The Aboriginal Peoples Act 1954 and the Recognition of Orang Asli Land Rights', ISSN 2229984X', UUMJLS, vol. 6, no. 1, 2015, pp. 063-083.

countries with substantial indigenous groups. ${ }^{31}$ In other regions, the practice of ensuing treaty arrangements between local sovereigns and the European powers, changed as the politics and economies in the East came increasingly under the influence of inter-European power rivalries based on the establishment of trade monopolies. ${ }^{32}$

\title{
Continuance of local custom and religions
}

The practice of respect to the local inhabitants was also evident by the continuance of local custom and religions. Since early period before colonization, the British demonstrated interest and sensitivities to the existence and use of local laws. In India, which directly influenced the British practice in the Malay Peninsula, the local laws mainly Hindu and Islamic law, were referred to in the courts established since the EIC's rule. ${ }^{33}$

In the Malay states, the local inhabitants were largely governed by their own laws and customs during the colonial period. ${ }^{34}$ Means described,

\begin{abstract}
The colonial government followed these principles: (1) the legal position of the Sultans was safeguarded, as laid down in the treaties; (2) the government was preserved as the distinctly Malay government which antedated any of the treaty arrangements made with the British; [and] (3) the Malays were considered the indigenous people, and the government accepted special responsibility for their welfare and the preservation of their rights as the "subject of the Sultan" in each state.
\end{abstract}

In the Malay Peninsula, Portuguese and Dutch left the administration of justice among their non-Christian Asian subjects in the hands of their political leaders. ${ }^{35}$ The Dutch practice was not really known but as it was their practice in Java to leave the natives to their own customs and laws, unless they clashed with what they regard as accepted principles of justice, Buss-Tjen suggests that this was also the case in Malacca. ${ }^{36}$ Maxwell was also of the same view that at 1825 when Malacca was taken by British, the land tenure in Malacca was governed by Malay customary land unchanged by the previous Rulers. ${ }^{37}$

British introduced a range of new laws in the region ${ }^{38}$ but regards were had to the existing rights and interests of the inhabitants, their local customs and religions. In providing for the common law to be the basis of legal system in the Crown colonies, the local laws and custom were not meant to be abrogated.

\section{The British Practice In The Straits Settlements And The Malay States}

\section{The Straits Settlements}

In Penang, the introduction of laws was mainly intended to solve the problem of legal chaos due to the absence of laws applicable to British subjects, which had led to injustice to the local inhabitants. ${ }^{39}$ Maxwell R observes

\footnotetext{
${ }^{31}$ Audun Sandberg, 'Collective Rights in a Modernizing North - On Institutionalizing Sámi and Local Rights to Land and Water in Northern Norway' (2008) 2(2) International Journal of the Common , [3].

${ }^{32}$ Marcia Langton and Lisa Palmer, 'Treaties, Agreement Making and the Recognition of Indigenous Customary Polities' in Marcia Langton et al (eds), Honour Among Nations?: Treaties and Agreements with Indigenous People (Melbourne University Press, 2004) 34, 37.

${ }^{33}$ John F. Riddick, History of British India: A Chronology (Greenwood Publishing Group, 2006), 184.

${ }^{34}$ Gordon P. Means, Malaysian Politics (Hodder and Stoughton, Second ed, 1976), 43.

${ }^{35}$ P.P. Buss-Tjen, 'Malay Law' (1958) 7(2) The American Journal of Comparative Law 248, 253: (W E Maxwell, 'The Laws and Customs of the Malays with Reference to the Tenure of Land' (1884) JSBRAS 72, 148.

${ }^{36}$ Buss-Tjen, above n 35, 148 .

${ }^{37}$ Maxwell, above n 35, 148.

${ }^{38}$ The First Charter of Justice introduced the common law of England to Penang in 1807, and the Second Charter of Justice introduced the common law to Malacca and Singapore in 1826. Another granted to the Straits Settlements was Charter of Justice 1855

${ }^{39}$ Kamoo v Thomas Turner Bassett (1808) 1 Ky. 1. (SB 8-9.): Stanley R held that the application of English law to the case which fact happened before the grant of the 1807 Charter is consistent with its objective to protect persons, liberties and properties of the natives from oppression and injustice inflicted by the British subjects.
} 
Izawati Wook, 'The Aboriginal Peoples Act 1954 and the Recognition of Orang Asli Land Rights', ISSN 2229984X', UUMJLS, vol. 6, no. 1, 2015, pp. 063-083.

in Regina $v$ Willans $^{40}$ that the First Charter of Justice 1807 respected native religions and usages and that the law in Penang before 1807 is the personal law of the local people. Cases, he felt, should be decided by the principles of natural law and equity which he said, in the case of British subjects, is English law. Many judges, however, found that English law was applicable in erroneous belief that there was no legal system existing in Penang before the grant of the First Charter of Justice. ${ }^{41}$

The same practice of respect to the local custom and existing rights was also seen in Singapore. ${ }^{42}$

In Malacca, ceded by the Dutch to the British, ${ }^{43}$ lands under Dutch grants were converted to English fee simple in 1839. The lands in the interior continued to be governed by local customary law which recognize private ownership of land by right of occupation and capable of being inherited. ${ }^{44}$ The customary tenure protected both the owner and his sub-tenant cultivator. ${ }^{45}$ Although English Deeds System was implemented to replace the former system of title including the customary law, the land rights held under customary land continued. ${ }^{46}$ British judges were often called upon to administer Islamic law as a matter of personal law. The colonial common law courts gave themselves the power to admit or refuse evidence of Islamic law and local customs when adjudicating cases involving such matters. ${ }^{47}$

It was generally believed that the introduction of English law into Penang in 1807 was on reason that the island was regarded as uninhabited at the time of Captain Light's occupation in 1789. ${ }^{48}$ The authority's official record dated 1795 did account for local settlements in Penang. ${ }^{49}$ Drawn from the context of classification of a region,

${ }^{40}$ Regina $v$ Willans (1858) 3 Ky. 16

${ }^{41}$ The judiciary in Penang was divided on the position of the custom and laws of the existing inhabitants. Judges in Yeap Cheah Neo v Ong Cheng Neo (1885) LR 6 PC 381; 1 Ky 326; and Fatimah v D Logan (1871) 1 Ky 255 for instance ruled that Penang was wholly uninhabited, "no trace of any laws having been established" and thus all settled in Penang became the subject of English law. In earlier case, Regina $v$ Willans (1858) $3 \mathrm{Ky} \mathrm{16}$, Sir Benson Maxwell doubted that the English law can be made lex loci by Captain Light and his companies which "were a mere garrison". However, Logan wrote that Malay Muslims such as Tengku Syed Hussain and their families were governed by their own custom and were not subjected to the English laws. Logan, J. R. (peny.) 1850. "Notices of Pinang," JIA, Jil. 4, p 655 cited in Mahani Musa, 'Keterlibatan Orang Melayu-Muslim dalam Persatuan Sulit di Pulau Pinang Sejak Abad ke-19 (Involvement of Malay-Muslims in Secret Societies in Penang since 19th Century)' (Paper presented at the Pengkisahan Melayu Pulau Pinang, Penang, 2001). That Penang was uninhabited was also refuted by recent studies.

${ }^{42}$ Yeap Cheah Neoh v Ong Cheng Neo (1872) 1 Ky. 326 PC: the English common law was in force in Singapore in so far as it is applicable, but that the Charter of 1826 provides that the Court of the Colony was to exercise jurisdiction as an Ecclesiastical Court in so far as the religions, manners and customs of the inhabitants will admit. See also, Isaac Penhas $v$ Tan Soo Eng (1953) MLJ 73 PC: The common law of England was in force in Singapore in 1937 except in so far as it was necessary to modify it to prevent hardships upon the local inhabitants who were entitled by the terms of the Charters of Justice to exercise their own respective religious customs and practices.

${ }^{43}$ Malacca was ceded by the Dutch to British through Anglo-Dutch Treaty of 1824.

${ }^{44}$ Sahrip v Mitchell (1879) Leic 466.

${ }^{45}$ Claridge R, Abdul Latif v Mohamed Meera Lebe (1829) 4 Ky 249.

${ }^{46}$ The English Deed System was implemented gradually until fully in 1886. Among efforts made to recognize the customary land except in Naning was Malacca Lands Customary Rights No. IX of 1886 (Ordinance 1886). The 1886 Ordinance was replaced by National Land Code (Penang and Malacca Titles) 1963 Act 518 in force in $1^{\text {st }}$ January 1966. The 518 Act extended the Torren system to replace the Deed System formerly in practice. The customary land in Naning, a district in Malacca, continued to be governed by Adat Perpatih up to present day.

${ }^{47}$ See, eg, Shaik Abdul Latif v Shaik Elias Bux [1915] 1 FMSLR 204. Respect of the existing law if exist could be seen in the judgment of Malkin, R in In the Goods of Abdullah (1835) 2 Ky. Ec. 8:

I believe it would be very difficult to prove the existence of any definite system of law applying to Prince of Wales' Island or Province Wellesley previous to their occupation by the English; but that law, whatever it was, would be the only law entitled to the same consideration as the Dutch law at Malacca; indeed, even that would not in general policy, though it might in strict legal argument; for there might be much hardship in depriving the settled inhabitants of Malacca of a system which they had long understood and enjoyed ... any man therefore who wishes his possessions to devolve according to the Mohamedan, Chinese, or other law, has only to make his Will to that effect, and the Court will be bound to ascertain that law and apply it for him.

${ }^{48}$ See, eg, Buss-Tjen, above n 35, 254.

${ }^{49}$ A note dated 1795 found in an old register of surveys recorded the existence of a fairly large Malay kampong (villages) of about 18 acres on the south bank of the Penang River. It also stated that the land had been occupied for 90 years, thus establishing a Malay population of Penang as early as 1705. Another smaller settlement further south was also mentioned, and it would seem that Penang was after all no virgin country at the time of its occupation by the British. What law prevailed 
Izawati Wook, 'The Aboriginal Peoples Act 1954 and the Recognition of Orang Asli Land Rights', ISSN 2229984X', UUMJLS, vol. 6, no. 1, 2015, pp. 063-083.

ceded or settled under the law of nation, absence of inhabitation was regarded as justifying the application of the discoverer's law on the land. On this presumption Buss-Tjen suggests that the British approach in introducing new laws, incidentally, is contrary to a principle of Dutch colonization which left the native populations to their own laws and customs, unless they clash with principles of justice and equity that they believed. He suggests that this difference is the cause of the different valuation of and approach to native adat law by the two colonizing powers. ${ }^{50}$

However, this view did not take into account the fact that the concept of rule over territory came into practice only by late $19^{\text {th }}$ century. The laws introduced to Penang were meant to be applicable to English subjects. Increasingly in $19^{\text {th }}$ century British tended to apply English law but personal laws continued. This is evident by the recognition and continuance of local institutions alien to English law. ${ }^{51}$

\section{Malay States under direct and indirect British rule}

The Malay states ${ }^{52}$ were legally sovereign and independent and British administrators applied the practices and customary laws of the inhabitants as they understood them. ${ }^{53}$ Minatur suggests that custom and practices of the local were viewed by the British as the common law of the people in those spheres of lives where it applied. ${ }^{54}$ But the content of customary laws were often misunderstood as they were unwritten, varied between districts and changed gradually through local judicial procedures. ${ }^{55}$ Hooker pointed out that there is a probability that the contents of the written codes were never applied as legal rules. ${ }^{56}$

Legislation was introduced in matters thought not to be provided for in local laws. In other areas, legislation was introduced to replace local laws to achieve what was thought to be better justice. For instance Adat [custom] criminal law was replaced by a Penal Code based on the Indian Penal Code, and a Criminal Procedure Code. Evidence laws were introduced on belief that it is more favorable to a suspect and in consonance with principle of natural justice. Local custom on law of evidence such as declaring an accused person guilty just because of "rumors spread by flies" or because the man did not stop to ask for betel, was considered as unjust and unreasonable. ${ }^{57}$

In the absence of local laws, civil law enactments ${ }^{58}$ provide reference to the common law and equity of England. But the application of the English law is subject to consideration of and consistency with the local circumstances. However, the reference to English common law and equity was the practice of judges even before the passing of the civil law enactment. ${ }^{59}$ In some cases, the judges found no recognizable laws, although the finding may have been erroneous. In some other cases, local custom was thought to be unreasonable, unjust

amongst these inhabitants is not known at all. As the island belonged to the Sultanate of Kedah we can only guess that either Kedah laws (adat temenggong) applied or else the local adat, whatever it was. Seen in this light, Penang was definitely not a settled colony: F. G. Stevens: A contribution to the early history of Prince of Wales' Island. JRAS-MB Vol. 7; C. F. Skinner: Notes and Queries Vol. 1, p. 6., cited in ibid, 254.

${ }^{50}$ Ibid, 255.

${ }^{51}$ See eg, the Six Widows Case 12 SSLR 120 (polygamy amongst Chinese was acknowledged); Muslim matrimonial law was recognized in the Ordinance No. V of 1880 and its amendments; an amendment in 1923 (No. 26 of 1923) applied Muslim law in matters of intestacy succession: ibid, 256.

${ }^{52}$ Perak, Selangor, Negeri Sembilan and Pahang were under direct rule of the British with a Resident appointed to assist in the States' administration. In 1895, the four states were confederated into Federated Malay States which lasted until the establishment of Federation of Malaya in 1946. The other Malay states were indirectly ruled by the British through a British Advisor.

${ }^{53}$ During the advent of British, some customary laws were coded into writing. Examples were Malacca Laws 1523, Pahang Laws 1596, Kedah Laws 1605, Johor Laws 1789, Minangkabau Digests, Perak Code and the Ninety-Nine Laws of Perak 1765.

${ }^{54}$ Joseph Minatur, 'The Nature of Malay Customary Law' (1964) 6(2) Malaya Law Review 327, 251.

${ }^{55}$ M. B. Hooker, 'The Interaction of Legislation and Customary Law in a Malay State' (1968) 16(3) The American Journal of Comparative Law 415; M. B. Hooker, 'The Challenge of Malay Adat Law in the Realm of Comparative Law' (1973) 22 International and Comparative Law Quarterly 492.

${ }^{56}$ Hooker, above n 55, 497.

${ }^{57}$ Buss-Tjen, above n 35, 258.

${ }^{58}$ Civil Law Enactment 1937 (Federated Malay States). The provision was extended to other Malay states in 1951 and to the whole Federation in 1956.

${ }^{59}$ Government of Perak v AR Adams [1914] 2 FMSLR 144 (tort action); Buss-Tjen, above n 35, 256. 
Izawati Wook, 'The Aboriginal Peoples Act 1954 and the Recognition of Orang Asli Land Rights', ISSN 2229984X', UUMJLS, vol. 6, no. 1, 2015, pp. 063-083.

and against public policy. ${ }^{60}$ Terrel Ag. CJ suggests in Motor Emporium v Arumugam ${ }^{61}$ that the Courts on many occasions acted on equitable principles, not because English rules of equity applied, but because such rules happen to conform to the principles of natural justice. ${ }^{62}$

In effect, extensive laws based on English principles were gradually introduced. One reason was the difficulty in determining the exact local custom. ${ }^{63}$ Another was the Anglocentric perspective of the English trained lawyers. Influenced by social evolutionism they believed that Britain was the superior nation. This belief was used to justify colonization in the $17-18^{\text {th }}$ centuries and shaped their perspectives towards the status of local people and the standard of their laws. The moral imperative of 'the white man's burden' reflected a belief that Christian nations should guide less civilised societies to enlightenment. ${ }^{64}$

\section{Preservation of Local Laws}

\section{Privilege of The Malays As Indigenous Groups}

The colonial practice of recognizing indigenous rights laid the basis for the present day laws relating to the protection and special privilege of indigenous groups specifically the Malays in the Malay Peninsula. Malay rights to land were recognized through Malay ancestral land protection policies and Malay Reservation legislations aiming to safeguard certain areas for Malays. The aim was to protect the local people's land from being sold to the non-Malays following the rubber rush of 1910.65 The first Malay Reservation legislation was

${ }^{60}$ In Re The Will of Yap Kwan Seng, Deceased [1924] 4 FMSLR - a trust for ancestral worship was held as not for public religious or charitable use and infringe the rule against perpetuities.

${ }^{61}$ Motor Emporium v Arumugam [1933] MLJ 276

${ }^{62}$ See also, Jamil bin Harun v Yang Kamsiah [1984] 1 MLJ 217: Lord Scarman:

[I]t is for the courts of Malaysia to decide, subject always to the statute law of the Federation, whether to follow English case law. Modern English law may be persuasive, but are not binding. In determining whether to accept their guidance the courts will have regard to the circumstances of the States of Malaysia and will be careful to apply them only to the extent that the written law permits and no further than in their view it is just to do so. The Federal Court is well placed to decide whether and to what extent the guidance of modern English authority should be accepted.

${ }^{63}$ This difficulty was noted by many writers who researched customary law in the region. See, eg, Buss-Tjen, above n 35 ; Hooker, above $\mathrm{n}$ 55. Although there were some digests of law, including the Laws of Malacca and the Ninety Nine Laws of Perak, the enforceability of the written laws was doubted. Some Qadhis [judges] of districts (judges administering Islamic law) who were often called upon to clarify the custom of the local were not really familiar with the exact adat in practice but instead gave the content of Islamic law that they knew but not in practice locally. Some qadhis having education background from the Middle East countries were resistant towards customs as practiced by the local people. Whereas local custom is accepted by Islamic law as a source of law, the qadhis took narrow approach towards Islam and regard local custom as unIslamic, thus imposing their view upon the local people on what laws that was supposed to regulate them.

${ }^{64}$ See eg, Charles Hirschman, 'The Making of Race in Colonial Malaya: Political Economy and Racial Ideology' (1986) 1(2) Sociological Forum 330; Daniel P. S. Goh, 'Imperialism and 'Medieval' Natives: The Malay Image in Anglo-American Travelogues and Colonialism in Malaya and the Philippines' (2007) 10 International Journal of Cultural Studies 323; S.H. Alatas, The Myth of the Lazy Native: A Study of the Image of the Malays, Filipinos and Javanese from the 16th to the 20th Century and Its Function in the Ideology of Colonial Capitalism (Frank Cass, 1977).

${ }^{65}$ Paul H. Kratoska, '"Ends That We Cannot Foresee": Malay Reservations in British Malaya' (1983) 14(1) Journal of Southeast Asian Studies 149, 151-2: In Selangor, a category of 'customary land' was created in 1891 land legislation to provide a security of tenure (referred to as 'a permanent, transmissible, and transferable right of use and occupancy'. Surveys of customary land were to be rudimentary but less costly than the surveys required for land involved in commercial transactions and, accordingly, less of a burden on the finances of a landholder. The restrictive ownership provisions were removed from the law upon disagreement by some portions of the communities. But in 1'customary land' was abandoned in the Land Enactments. The enactments allowed for registration of title to land upon survey in a government maintained register, the entry constituting the title. In 1926, a revised land code, (put into force in 1928) consolidated the two laws in a single enactment.

${ }^{65}$ The Malay Reservation Enactment (1913) (FMS), which was repealed and replaced by the Malay Reservation Enactment (1933) (Cap.142). Similar laws were also passed for example in the State of Kelantan (1930), Kedah (1931), Perlis (1935), Johor (1936) and Terengganu (1941). For analysis on the unforeseen impact incompatible with the objective of protection of the indigenous Malay, see ibid.897 land enactments (Land Enactment and Registration of Titles Enactment enacted in all FMSs) the term 'customary land' was abandoned in the Land Enactments. The enactments allowed for registration of title to land upon survey in a government maintained register, the entry constituting the title. In 1926, a revised land code, (put into force in 1928) consolidated the two laws in a single enactment. 
Izawati Wook, 'The Aboriginal Peoples Act 1954 and the Recognition of Orang Asli Land Rights', ISSN 2229984X', UUMJLS, vol. 6, no. 1, 2015, pp. 063-083.

enacted in 1913.66 Subsequently, upon independence, the Malay rights and their special position are safeguarded in the 1957 Constitution extending the position already provided in the constitution of the Federation of Malaya 1948.

The local people were also left to the customary laws to practice. This includes the land held under local adat or Muslim laws. British Land Regulations required landowners to record their titles in the Land Offices, and provided a procedure for the transmission of lands to heirs of a deceased holder, without indicating what the law of succession was. The practice of the Collectors was to apply adat which was often mixed with Islamic law.67

Statutes were also enacted to protect the land of local peoples and their customs. This included the Malacca Land Act 1861, Customary Tenure Enactment 1909 in Negeri Sembilan which restricted dealings involving ancestral lands and the Laws of Perak (Enactment No. 6 of 1951). ${ }^{68}$

Institutional means were also established to protect local property. For instance to aid and assist the Ruler in matters concerning the Muslim religion and adat, a Council of Religion and Malay Custom ${ }^{69}$ was established in all states except Selangor. ${ }^{70}$ The role of Islamic law was preserved in a formalized Syariah Court that operated under the jurisdiction of the states. ${ }^{71}$ Nonetheless, conflict often arose over what laws were applicable to cases involving personal matters including validity of wills ${ }^{72}$ and marriage. ${ }^{73}$ The conflict may arise from the difference in perspectives among judges towards the exact laws practiced by local people.

\section{Land and forestry legislations and the existing rights}

The policy to respect the interests of the existing inhabitants may have also influenced the legislations governing the administration of land, customary land and forests. There is nothing in the legislation introducing the Torren system in the Malay states that denies the existing local rights. In Sahrip v Mitchell,74 failure to take out the proper title for occupied land under the relevant legislation75 did not make the occupier liable for ejectment. Similarly in Roberts @ Kamarulzaman v Ummi Kalthom,76 the provisions of the Land Code with regard to indefeasibility of title of registered land did not affect entitlements under Malay customary law in matter of 'jointly acquired property'. Legislation providing for reserves of forests and sanctuary that calls, by notice, for any claims of interests in the proposed reserve, reflects the same policy.

However legislation regulating land administration in particular was introduced under presumption that the locals had no ownership rights in the soil but a mere usufruct under local custom. Maxwell compared this to English law:

\footnotetext{
${ }^{66}$ The Malay Reservation Enactment (1913) (FMS), which was repealed and replaced by the Malay Reservation Enactment (1933) (Cap.142). Similar laws were also passed for example in the State of Kelantan (1930), Kedah (1931), Perlis (1935), Johor (1936) and Terengganu (1941). For analysis on the unforeseen impact incompatible with the objective of protection of the indigenous Malay, see ibid.

${ }^{67}$ Buss-Tjen, above n 35, 257 citing E. N. Taylor: Divorce and Inheritance. JRAS-MB 21 Part 2; E. N. Taylor: Malay Family Law. JRAS-MB 15. The office of 'collector' was created by British administration in India since 1772 to replace the position known as Supervisor: See Riddick, above n 33, 186.

${ }^{68}$ Sahrip v Mitchell \& Anor (1870) Leic, 466, Sir P. Benson Maxwell CJ held that the Malacca Land Act 1861 plainly refers to and recognizes the same customary tenure when it declares that 'all cultivators and resident tenants of lands ... who hold their title by prescription are, and shall be, subject to the payment of one-tenth of the produce thereof to the Government'.

${ }^{69}$ The institution's name in Malay was Majlis Ugama Islam dan Adat Melayu.

${ }^{70}$ Buss-Tjen, above n 35, 257.

${ }^{71}$ Ninth Schedule of the Federal Constitution.

${ }^{72}$ See above $\mathrm{n} 47$.

${ }^{73}$ See, eg, In re Maria Huberdina Hertogh; Adrianus Petrus Hertogh v Amina binte Mohamed [1950] MLJ 215; [1951] MLJ 164 (Singapore): the validity of marriage of a Dutch girl who was adopted and raised as a Muslim was held to be determined by her lex domicili. The marriage under Muslim law was held as invalid according to Dutch law as the girl, being a minor, had no capacity to marry. But the judge, Brown J, also considered the position of Islamic law in the matter. He found that under Islamic law the marriage was also invalid as the kadhi [judge] who perfomed the marriage had no authority as a valid guardian (wali) to perform the marriage (page 15).

74 (1870) Leic, 466 Sir P. Benson Maxwell CJ.

${ }^{75}$ Act XVI of 1839 (Malacca).

${ }^{76}$ Roberts@ KamarulzamanvUmmi Kalthom [1963] 1 MLJ 163.
} 
Izawati Wook, 'The Aboriginal Peoples Act 1954 and the Recognition of Orang Asli Land Rights', ISSN 2229984X', UUMJLS, vol. 6, no. 1, 2015, pp. 063-083.

No subject in a Malay state can lawfully claim to hold any property in land approaching (the English) freehold or fee simple tenure. ${ }^{77}$

In drafting legislation for land administration in the Malay states, Maxwell made the Sultan the owner of the lands in his state. David Wong refutes this claim, pointing out that none of the old Malay Digests contained a statement that the Sultan was the owner of the lands in his state. ${ }^{78}$ Kratoska also suggests that pre-colonial land tenure in the Malay Peninsula is imperfectly understood. Adat or custom legal codes indicated that peasants enjoyed security of tenure so long as their lands remained under cultivation. On the other hand British accounts suggest that the Malay aristocracy could and did seize peasant properties at will. ${ }^{79}$

\section{The Treatment Towards The Orang Asli Land In The Past And The Origin Of The APA As A Means Of Protecting The Orang Asli Land}

\section{The Orang Asli And The Malays As Distinct Polities}

The principle of equality requires the same respect to the rights of the aborigines, similar to the native Malays. During the colonial era, the aborigines were regarded as another group of indigenous peoples to the peninsula. This classifications of 'natives' and 'aborigines' had direct influence over the colonial policies in relation to many aspects including administration of land and resources, custom and religions.

From the perspective influenced by the theory of social Darwinism, the Malays were regarded by the British as subjects of the main polities on the peninsula, who were considered as higher in the civilization scale. ${ }^{80}$ The other tribal groups, the ancestors of the present Orang Asli, were regarded as the aborigines, whose status of civilization was regarded as lower than the Malays from the European perception. ${ }^{81}$ In their eyes, the aborigines were the 'representative of one of the wildest races of mankind' ${ }^{82}$ This belief on standard of civilization influenced or justified the colonization by the Europeans and explains the difference in the treatments between the two groups. The distinction between the groups was reinforced in their classification of natives through

\footnotetext{
${ }_{77}^{77}$ Maxwell, above n 35, 1122.

${ }^{78}$ David SY Wong, Tenure and Land Dealings in the Malay States, Singapore University Press (1975), 16, fn 29. David points out that Perak Code states that the forests belonged to no man. See also The Laws of Melaka (Undang-undang Melaka). It contains no provision about the ownership of land by Ruler or Sultan. S 20.1 provides:

With regard to 'dead land', nobody has property rights to it, (when) there is no sign of its being under cultivation by someone, then certainly nobody can lay a claim to that land. If someone cultivates it into (a rice-field, be it) a huma or ladang or sawah or bendang, no one can proceed against him. That is what is understood by dead 'land'.

The original text:

Adapun tanah mati itu tiada siapa yang empunya hak, tiadalah alamatnya empunya dia, niscaya tiadalah ada lagi perkataannya pada tanah itu. Jikalau diperbuatnya huma atau ladang atau sawah atau bendang, tiada siapa dapat berkata-kata lagi akan dia. Itulah tanah mati nama dia.'):
}

Liaw Yock Fang, Undang-undang Melaka (The Laws of Melaka), Bibliotheca Indonesica (Koninklijk Instituut, 1976), 1101.

${ }^{79}$ Paul H. Kratoska, 'The Peripatetic Peasant and Land Tenure in British Malaya' (1985) 16(1) Journal of Southeast Asian Studies 16, 40. He suggests that the British version was based largely on statements made to various officials and not on the evidence of particular instances where such occurrences took place, and without further empirical evidence the question of whether and under what circumstances the aristocracy could override customary prescriptions cannot be answered.

${ }^{80}$ Alfred Russell Wallace in 1865, following Henry Morgan's three stages of social evolution, describes the aborigines as 'savages' and less civilized than the Mohamedan Malays. The aborigines were referred to in early writings as Semang, Sakai, Jacoon and Orang-Utan, among other names, which were derogatory indicating the general perspectives towards the people: A. R. Wallace, 'On the Varieties of Man in the Malay Archipelago' (1865) 3 Transactions of the Ethnological Society of London 196.

81 Alice M Nah, '(Re) Mapping Indigenous 'Race'/Place in Postcolonial Peninsular Malaysia' (2006) 88(3) Human Geography 285, 286.

${ }^{82}$ Skeat, W. W. 'The wild tribes of the Malay Peninsula' (1902) 32 The Journal of the Anthropological Institute of Great Britain and Ireland 124, 125 quoted in Rusaslina Idrus, 'The Discourse of Protection and the Orang Asli in Malaysia' (2011) 29(Suppl. 1) Malaysian Studies 53, 56. 
Izawati Wook, 'The Aboriginal Peoples Act 1954 and the Recognition of Orang Asli Land Rights', ISSN 2229984X', UUMJLS, vol. 6, no. 1, 2015, pp. 063-083.

policies and practices during the British colonial era. It was also believed that the Orang Asli would gradually assimilate with the Malays,$^{83}$ and they would be protected under the same privilege provided by the laws to the Malays.

\section{The Lands Occupied By The Orang Asli Were Considered As Belonged To Them}

There is ample evidence to show that the treatment of the Orang Asli communities was on the basis that that they owned their land. British records indicated that certain territories belonged to the Orang Asli. ${ }^{84}$ In 1861, a British colonial officer refused an application of land located in Ulu Sungei Langat up to Pahang border by one Jaafar on the grounds that the rights to the area were recognized as belonging to an Orang Asli group living in the area ${ }^{85} \mathrm{Juli}$ also pointed out that prior to independence, Orang Asli areas were marked on land register maps. ${ }^{86}$

Land recognized as the 'country of the Sakai ${ }^{87}$ was not included in the general land registration system. The aim was to protect the aborigines from being exploited by selling off their land for unfair consideration which had occurred if they were issued formal titles. ${ }^{88}$ It is evident that a factor considered by the administrators in the alienation of land, in the form of grant of title, was the level of civilization of the applicants. ${ }^{89}$ The only possible explanation to this, based on the standard of civilization that they believed, is that the aborigines were regarded as low and therefore they were subjected to greater government control with objective of protecting them from exploitation.

The pervasive government control was similar to the British practice in other jurisdictions. In Canada, the Indian Act of 1876 consolidated and imposed a system of pervasive government control over the First Peoples and their lands. In Brazil, legislation established Indians as wards of the state and set in motion government programs to manage their affairs and facilitate their adoption of Euro-Brazilian ways. The US followed the British by constituting a vast government bureaucracy to consolidate and manage its system of Indian reservations. ${ }^{90}$ This system was developed from trusteeship doctrines akin to those proposed by Vitoria, a

\footnotetext{
${ }^{83}$ Wallace, above $n 80$.

${ }^{84}$ See, eg, David Radcliffe, 'The Peopling of Ulu Langat' (1969) 8 Indonesia 155.

${ }^{85}$ Ibid, 170-2 document of the Ulu Langat District Office no. DOUL. 610/02). In census return on 1884, beyond Ulu Langat area was considered as 'Sakai country'. It was also recorded that migrants who came from Minangkabau (now in Indonesia) apply for permission from the Orang Asli's leader to occupy their land.

${ }^{86}$ The initiative to mark Senoi areas in Perak were taken by HD Noone, the ethnographer of Taiping Museum in early $20^{\text {th }}$ century. The Senoi areas were marked as 'Sakai Ladang' or 'Sakai Reserve', together with the name of the penghulu (head of community) of each of these areas. Juli Edo, Claiming Our Ancestors' Land: An Ethnohistorical Study of Seng-oi Land Rights in Perak, Malaysia (PhD Thesis, Australian National University, 1998), 314, stated

Subsequently, all marks indicating Seng-oi [Senoi] areas were erased from the new map reproduced by the independent Malaysian government, leaving no Seng-oi land on the map. This then became a major problem when the state based land transactions solely on the map without considering its reality on the ground. As a result most of the Seng-oi areas were approved to other parties, the majority of which were state subsidiaries responsible for projects such as oil palm estates, logging, hydro-electric dams, and recently, tourism industries.
}

${ }^{87}$ In the early writing about the aborigines, the word Sakai is the name normally referred to aborigines who are now grouped as Senoi.

${ }^{88}$ Radcliffe, above n 84, 172 citing Ulu Langat Land Office files 1242/00 and Selangor Secretariat files 6443/00: Radcliffe pointed out that in 1900 the Resident-General ruled that there would be no extension to the Sakai of the system instituted for recording land titles.

89 An application for the grant of temporary occupational license to a group of aborigines was allowed as they were considered as 'civilized as any of their Malay neighbour's'. Sakai Reserve was considered as not suitable in their case: File 825/1939: Excision of a portion of land which had been planted with rubber by Sakais from the Malay Reservation in Mukim Luit, Pahang (ANM - 1957/0534944).

${ }^{90}$ Anaya, above n 30, 32-3. 
Izawati Wook, 'The Aboriginal Peoples Act 1954 and the Recognition of Orang Asli Land Rights', ISSN 2229984X', UUMJLS, vol. 6, no. 1, 2015, pp. 063-083.

prominent thinker in early formation of international law, ${ }^{91}$ as the parameters for non-consensual exercise of authority over indigenous peoples. ${ }^{92}$

\section{The APA: Its Origin And Aim To Protect The Orang Asli Land}

The first federal legislation specific to the aboriginal peoples was the Aboriginal Peoples Ordinance 1954 (APA),${ }^{93}$ adopted from the Perak Aboriginal Tribes Enactment 1939. ${ }^{94}$ The Perak legislation ostensibly sought to address the developments that were dispossessing the aboriginal people as well as the health and social problem faced by them. ${ }^{95}$ Its provisions included the establishment of Orang Asli Areas and Orang Asli Reserves.

It also created the position of 'Protector for Aborigines'96 with similar duties as those created in Australia, including protection of their land from transgression by the settlements of new settlers. The position of the Protector of Aborigines was first created in Australia upon recommendation in a report by the Select Committee of the House of Commons, Select Committee on Aborigines (British Settlements). The report recommended for the appointment of Protectors of Aborigines. Their duties include to safeguard the rights of the Aboriginal Peoples encroachment on their property and to protect them from acts of cruelty, oppression and injustice. ${ }^{97}$

The same approach was also adopted by the APA, a federal legislation introduced in 1957 following security concern during communist insurgency (1948-1960). The legislation was taken as a measure to address the security threat posed by the position of the Orang Asli. Most of them were living in the forests and many were used by communist guerrillas to supply their needs. ${ }^{98}$ This circumstance explains the extensive government control of the Orang Asli in the APA.

Similarly, at a policy level announced in 1957, it was proposed that the hereditary land rights of the various local groups should be recognized and they should not be forced to move against their will for any economic or political reasons. ${ }^{99}$

\section{The APA, The Constitutional Special Position And The Framework To Protect The Orang Asli Land}

\footnotetext{
${ }^{91}$ G C Marks, 'Indigenous Peoples in International Law: The Significance of Francisco de Vitoria and Bartolomê de Las Casas' (1992) 13 Australian Year Book of International Law 1, 8 citing Scott JB, The Spanish Origin of International Law (1932) IX; Brierly JL, The Law of Nations, 6th ed (1963); Sanders, 'The Re-emergence of Indigenous Questions in International Law' (1983) 3 Canada Human Rights Yearbook 12-30. Sander notes and endorses the role of Francisco and Las Casas in asserting indigenous rights at an early stage of international law, but he also observes that Francisco does provide some grounds for justifying colonialism, especially if the subjugation of the indigenous people should appear to be for their benefit, eg the doctrine of trusteeship: page 5 cited in ibid, 12 .

${ }^{92}$ Anaya, above n 30,31 .

93 Ordinance No. 3 of 1954. The Ordinance was revised as the Aboriginal Peoples Act 1954 in 1974 (Act 134). This was mainly in response to communist resurgence post the $2^{\text {nd }}$ World War to establish a special administrative regime to control the aborigines from the communist influence.

${ }^{94}$ State of Perak Enactment No. 3 of 1939

${ }^{95}$ Noone, H. D. 'Report on the settlements and welfare of the Ple-Temiar Senoi of the Perak-Kelantan watershed'. (1936) Journal of the Federated Malay States Museums 19(1): 1-85, cited in Idrus, above n 82, 60.

${ }^{96}$ Ibid, 60.

${ }^{97}$ House of Commons Select Committee on Aborigines (British Settlements), Report, Parl Paper, House of Commons no $425,1837,84$.

98 J. D. Leary, Violence and the Dream People: The Orang Asli in the Malayan Emergency, 1948-1960. (Center for International Studies, Ohio University, 1995).

99 'The Long Term Administration of the Aborigines of Malaya 27 May 1957 ANM - 2005/0018322 (Malaysia National Archive)' (1957).
} 
Izawati Wook, 'The Aboriginal Peoples Act 1954 and the Recognition of Orang Asli Land Rights', ISSN 2229984X', UUMJLS, vol. 6, no. 1, 2015, pp. 063-083.

The APA is a specific legislation addressing aboriginal affairs. ${ }^{100}$ It establishes a specific framework comprising both levels of government, federal and states. It is argued that the ultimate objective of the Act is to protect and preserve the rights and interests of the aborigines including their autonomy, identity and land from competing economic and political forces.

The legislation represents a benevolent intention to protect the interests, autonomy and the way of life of the aborigines as minorities. It covers most aspects of their lives including who is Orang Asli, their education and their security. Although the objective appears paternalistic, the approach was considered at the time as a 'way to protect'. Gopal Sri Ram J in Sagong (2004) characterizes the APA as a human rights statute as it contains a comprehensive statement of the 'human rights' of the aborigines. Such a statute is pre-eminent over ordinary legislation from its quasi-constitutional status. ${ }^{101}$ Theoretically, it is an indication given by the public through the legislature that the law and the 'values that it endeavours to buttress and protect' are more important than other ordinary legislation. ${ }^{102}$ It gives rise 'to individual rights of vital importance, rights capable of enforcement', in a court of law. ${ }^{103}$

Under the Federal Constitution, the special position of the Orang Asli, referred to as the 'aborigines', is recognized. Apart from the general provisions, including those that aim to safeguard the fundamental liberties of all citizens which are equally applicable to the Orang Asli, there are specific provisions that are particular to the Orang Asli:

(a) First, the savings clause in the equality provision allows for discriminatory legislation such as the Aboriginal Peoples Act 1954 (APA) for the 'protection, well-being or advancement' of the aborigines (Art 8(5)(c)). ${ }^{104}$ Although the Constitution specifically provides for the special position of other groups who are the natives of the land, the Malays and natives of Sabah and Sarawak, the legitimate interests of other groups are also protected by the same highest authority of the Federation (Art 153). ${ }^{105}$ It is suggested that both provisions should be read as an embodiment of the principle of substantial equality in terms of outcomes within certain classes of society. In other words, the provisions amount to an elaboration of equality rather than an exception to the general principle of equality. ${ }^{106}$

(b) Second, the welfare of aborigines is specifically placed under the jurisdiction of the Federal Government. ${ }^{107}$ Even so, it is the responsibility of the states' executive authority to ensure compliance with any federal law applying to the states and not to impede or prejudice the exercise of the executive authority of the Federation. ${ }^{108}$

(c) Third, within the composition of the Senate in the Parliament, there must be members who 'are capable of representing the interests of aborigines'. 109

\footnotetext{
${ }^{100}$ For the background that led to the enactment of the APA, see Idrus, above $\mathrm{n} 95,53$. Briefly, this Act was inherited from British colonial rule, and its precursor, the Perak Aboriginal Tribes Enactment 1939. The 1954 law, which was initially referred to as the Aboriginal Peoples Ordinance (1954) and later revised as the Aboriginal Peoples Act (1974), was essentially an adoption of the 1939 Enactment. The earlier law, based largely on recommendations by H. D. Noone, a field ethnographer and curator for the Federated Malay States Museum Department, attempted to protect the Orang Asli's way of life.

${ }^{101}$ Kerajaan Negeri Selangor v Sagong bin Tasi [2005] 6 MLJ 289, 303.

102 Ibid, 303 citing Insurance Corporation of British Columbia v Heerspink [1982] 2 SCR 145, 303. (Lamer J Supreme Court of Canada).

${ }^{103}$ Ibid, 304 citing Canadian National Railway Co v Canada (Canadian Human Rights Commission) [1987] 1 SCR 1114, 1134 (Dickson C).

${ }^{104}$ Federal Constitution art 8(5)(c): 'This Article [Art 8] does not invalidate or prohibit any provision for the protection, well-being or advancement of the aboriginal peoples of the Malay Peninsula (including the reservation of land) or the reservation to aborigines of a reasonable proportion of suitable positions in the public service'. Art 8(1) states: 'All persons are equal before the law and entitled to the equal protection of the law'.

105 Federal Constitution, art 153(1): 'It shall be the responsibility of the Yang di-Pertuan Agong to safeguard the special position of the Malays and natives of any of the States of Sabah and Sarawak and the legitimate interests of other communities in accordance with the provisions of this Article'.

${ }^{106}$ See above: Chapter 3.II.D. See also, Yogeswaran Subramaniam, 'The UNDRIP and the Malaysian Constitution: Is Special Recognition and Protection of the Orang Asli Customary Land Permissible?' (2011) 2 Malayan Law Journal cxxvi referring to the approach taken by the Indian Supreme Court.

${ }^{107}$ Federal Constitution Ninth Schedule Federal List Item 16.

108 Ibid, art 81.

${ }^{109}$ Ibid, art 45(2).
} 
Izawati Wook, 'The Aboriginal Peoples Act 1954 and the Recognition of Orang Asli Land Rights', ISSN 2229984X', UUMJLS, vol. 6, no. 1, 2015, pp. 063-083.

There is no specific mention in the Constitution of the protection of the land and resources of the aborigines. But, as will be shown in the next section, the protection of land and resources as their hereditary rights based on their customary law is a core element embodied in the notion of welfare concerning the aborigines. This understanding of the nature of aboriginal land rights is evident in existing legislation and the statements of policies by the executive government.

\section{Extensive Government Control Is To Protect Orang Asli Land}

Passed under the same belief on the standard of civilization and the contingency of the event that led to the legislation, the APA creates extensive power over the lives of the Orang Asli to the Director General of Orang Asli Affairs, a special position created at Federal level concerning the administration, welfare and advancement of the Orang Asli. This position, as an agent of the Federal Government, is assisted by a government agency, the Orang Asli Advancement Department, ${ }^{110}$ also funded by the Federal Government. At the state level, where land and resources are subject to the control of State Authorities, the legislation provides for the power of the authorities to create reservation of land for the occupation and use of the Orang Asli to the exclusion of others. As established under the common law, this power is the legal duty of the State Authorities to the aborigines as the fiduciary. ${ }^{111}$ The APA limits the power of the State authorities to alienate land or grant licenses affecting land declared as Aboriginal Areas APA by subjecting them to consultation with the Director General. ${ }^{112}$ Alienation or grant of land within an Aboriginal Reserve could only be made to aborigines who normally reside within the reserve. ${ }^{113}$ This is in a way provides for a system of check over the grant of land that affect the Orang Asli land.

The power of the Director General is in no way absolute. The legislation respects the autonomy of the leadership of the Orang Asli over their communities. It expressly states that the power of the Director General does not preclude the 'aboriginal headman from exercising his authority in matters of aboriginal custom and belief'. 114

This is the same pattern taken by British following the Royal Proclamation 1763 in North America that restricted conveyance of the Indian land to protect the Indian land. The British policy later influenced the US government policy in dealing with the Indian in the US territories. For example the Indian Intercourse Act adopted in 1790 controlled trade and travel in Indian territories and restricted conveyance of Indian lands without the consent of the US government. ${ }^{115}$

\section{The Mechanisms To Protect The Orang Asli Land And Resources.}

There are several mechanisms created by the APA to protect the Orang Asli land:

First, the creation of reserves and the duty of States. The APA provides for the creation of reserves to protect the land of the Orang Asli: Aboriginal areas (s 6) and Aboriginal Reserve (s 7). ${ }^{116}$ The Aboriginal Areas

\footnotetext{
110 The name of the department in Malay is Jabatan Kemajuan Orang Asli (JAKOA). Previously it was known as Orang Asli Affairs Department or Jabatan Hal Ehwal Orang Asli (JHEOA).

${ }^{111}$ Kerajaan Negeri Selangor v Sagong bin Tasi [2005] 6 MLJ 289. See also, Bato' Bagi v Kerajaan Negeri Sarawak (2011) 6 MLJ 297.

${ }^{112}$ Ss 6(2)(iii)-(iv) Aboriginal Peoples Act 1954.

${ }^{113}$ S 7(2)(iv) Aboriginal Peoples Act 1954.

${ }^{114}$ S 4 Aboriginal Peoples Act 1954 (Malaysia):

The Director General shall be responsible for the general administration, welfare and advancement of aborigines: Provided that nothing in this section shall be deemed to preclude any aboriginal headman from exercising his authority in matters of aboriginal custom and belief in any aboriginal community or any aboriginal ethnic group.

115 Benjamin J. Richardson, 'The Dyadic Character of US Indian Law' in Benjamin J. Richardson, Shin Imai and Kent McNeil (eds), Indigenous Peoples and the Law: Comparative and Critical Perspectives (Hart Publishing, 2009) 51, 59.

116 Aboriginal Areas is meant for areas exclusively or predominantly inhabited by the aborigines, but unlikely to remain permanent in the area (s 6(1), s 7(1)(i)). Aboriginal Reserves are meant for areas exclusively inhabited by the aborigines ((s 7(1)). The Aboriginal Areas were created to accommodate mobile aborigines, whereas the Reserves were created for settled aborigines. The purpose for the differentiation was explained in British Archives, The Aboriginal Tribes Enactment, Protection of Aborigine, Colonial Records CO 717/144/12 (1939).
} 
Izawati Wook, 'The Aboriginal Peoples Act 1954 and the Recognition of Orang Asli Land Rights', ISSN 2229984X', UUMJLS, vol. 6, no. 1, 2015, pp. 063-083.

Were created to accommodate nomadic aborigines, whereas the Reserves were created for settled aborigines. ${ }^{117}$ Both aboriginal reserve and areas are protected against the creation of Malay Reservations and sanctuaries for wildlife, ${ }^{118}$ creating priority over these other interests. Within the aboriginal reserves, forest reserve may not be created. ${ }^{119}$ Any disposal of land by the State could only be made to the aborigines of the aboriginal communities normally resident within the reserve. ${ }^{120}$ No temporary occupation within the reserve is allowed to nonaborigines. ${ }^{121}$ The High Court in Kijang Mas $(1991)^{122}$ held that the aborigines have exclusive rights to forest produce in declared aboriginal reserves even when it is still awaiting gazettal after state approval. The state has no power to issue logging permits in that area to any person who is not Orang Asli. ${ }^{123}$ Another law that allows for creation of reserve for the Orang Asli is s 62 National Land Code. ${ }^{124}$

The court in Sagong, following North American common law, held that the creation of reserve is the duty of the State Authority as fiduciary having legal powers and responsibilities to protect the people. ${ }^{125}$ The intention for the creation of reserves under the law is to prohibit the alienation to, or dealing by the State, of land in aboriginal area with, a non-aborigine. It merely reflects the permanent nature of the title vested in the plaintiffs. The court rejected the argument that in the event the State authority does not exercise the power, the aborigines would have nothing in the manner of any title to or interest in the land. Such argument, it said, frustrates the purpose of the Act to protect the welfare of the aboriginal peoples. The court considered that land is a very valuable socio-economic commodity so it would not be the intention of the legislature to deprive people of their customary title at common law. ${ }^{126}$

However in practice, most of the Orang Asli's traditional lands are not protected under the APA. ${ }^{127}$ There are substantial areas inhabited by the communities which are not gazetted. ${ }^{128}$ Pahang, the state with highest number of Orang Asli population, decided not to create reservations under the APA after $1992 .{ }^{129}$ Some of areas approved but yet to be formally gazetted are also reported to have been reclassified as state land or alienated to

\footnotetext{
117 British Archives, The Aboriginal Tribes Enactment, Protection of Aborigine, Colonial Records CO 717/144/12 (1939) cited in Idrus, above $\mathrm{n} 95,64$.

118 Aboriginal Peoples Act 1954 (Malaysia), s 6(2) - for aboriginal areas; s 7(2) for aboriginal reserve).

${ }^{119}$ Ibid, s 7(2)(iii).

${ }^{120}$ Ibid, s 7(2)(iv).

${ }^{121}$ Ibid, S 7(2)(v).

122 Koperasi Kijang Mas v Kerajaan Negeri Perak [1991] CLJ 486

${ }^{123} \mathrm{Ibid}, 653$.

${ }^{124} \mathrm{~S} 62$ provides for power of State Authority to reserve any State land for any public purpose.

125 Sagong bin Tasi v Kerajaan Negeri Selangor [2002] 2 MLJ 591; Kerajaan Negeri Selangor v Sagong bin Tasi [2005] 6 MLJ 289. In the case, both State and Federal government had breached their fiduciary duties upon failure to gazette the Orang Asli land.

${ }^{126}$ Kerajaan Negeri Selangor v Sagong bin Tasi [2005] 6 MLJ 289, 306, 313. He also finds support in the affirmation of the Federal Court of the High Court and the Court of Appeal's decisions in Adong. The failure of a state government to gazette land occupied by Orang Asli is a breach of its fiduciary duty. This is also partly based on the fact that the government has knowledge that the land was occupied by the communities. The government is also aware that failure to gazette the land will affect the communities seriously and exposed to serious loss.

127 Colin Nicholas, The Orang Asli and the Contest for Resources (International Work Group for Indigenous Affairs, 2000)12, 32-34.

Suhakam, 'Report on the In-depth Discussion on Native Customary Land Rights of the Orang Asli in Peninsular Malaysia' (13 June 2009), 3; Hakimah Yaacob, 'Rights of Orang Asli in Peninsular Malaysia from legal perspectives concerning de jure systemic denial on continuity pro tempore rights to lands, ignorance of welfare and education ' (Paper presented at the Multiculturalism and Law, University of Malaya, Malaysia, 6-7 May 2008), 8; H. S. Lim, 'The Land Rights of the Orang Asli' in Land Issues in Malaysia (Consumers' Association of Penang, 2000) , 179 cited in Azmi Sharom, 'A Critical Study of the Laws Relating to the Indigenous Peoples of Malaysia in the Context of Article 8(j) of the Biodiversity Convention' (2006) 13 International Journal on Minority and Group Rights 53, 57. It states that, of the 83269.86 hectares of land which the Department of Orang Ash Affairs requested to the state governments to alienate as Orang Asli land, only 18587.26 hectares were under gazette.

${ }^{128}$ In 2006, Department of Orang Asli Affairs (JHEOA) identified the gazetted land as representing only $15 \%$, from 876 Orang Asli villages (JHEOA, 2006).See also, Nicholas, above n 12, 33-4; Salleh Buang, 'Still many unanswered questions', New Straits Times (Kuala Lumpur), Dec 6, 2008, 8.

${ }^{129}$ Interview data: Legal Advisor of a land and resource development office at federal level and senior officer of Orang Asli Affairs Department. The problem is also reported in Perak, a northern state in the Peninsula: Edo, above n 86, 16-7.
} 
Izawati Wook, 'The Aboriginal Peoples Act 1954 and the Recognition of Orang Asli Land Rights', ISSN 2229984X', UUMJLS, vol. 6, no. 1, 2015, pp. 063-083.

individuals or companies without the consent of the Orang Asli concerned. The total area reserved has also declined. ${ }^{130}$

Second, the right of occupancy: Apart from the provisions for aboriginal reserve and areas, the Act also provides for the power of State Authorities to grant to the aborigines the 'rights of occupancy of any land not being alienated or land leased for any purpose within any aboriginal area or aboriginal reserve'. This kind of right of occupancy is a kind of tenancy at will. ${ }^{131}$

Many suggest that this provision of tenant-at-will occupancy applies to all aborigines occupying land within areas declared as aboriginal reserves or areas. ${ }^{132}$ However, it is suggested that this provision is not applicable to the aborigines already living on the land. As the APA requires the creation of an aboriginal reserve and areas on land already 'predominantly or exclusively inhabited by aborigines', it is unlikely that there is a need for the state to make a grant of occupancy to the aborigines who have been living on the land. Due to this, it is possible that s 8 allows for the state authorities to allow other aborigines who are not habitually living in the reservation to occupy certain particular areas, either unalienated state land or aboriginal reserves/areas. This may apply in the situation of relocations of the other aborigines when it is necessary.

Based on this argument, the effect of the section should not be applicable to the land reserved under s 6 and s 7 . There is nothing to suggest that it could also apply to any other customary land of the Orang Asli to which they have existing rights, recognized by the common law, which is outside the purview of the APA. Therefore, it is submitted that it is a mistake to state that all lands held by the Orang Asli have the status of tenancy at will.

Third, restriction of dealing by the aborigine: The Act also aims to protect the land of the aborigines by requiring any land dealings by the aborigines to have the consent of the Director General. Within aboriginal areas, the disposal of land and grants of licences to a non-aboriginal person by the state for collection of forest produce must only be made in consultation with the Director General of the Orang Asli. ${ }^{133}$ The Director General, appointed under the Act, is entrusted with a wide power for the purpose of safeguarding the interests of the aborigines against manipulation. It is clear that the policy imbued in the Act is to protect the peoples' land from loss and them from dispossession. In reality, however, the Director-General, as legal representative of the Orang Asli, has often used this power to assign to others the rights of the Orang Asli to their land.

Fourth, priority of aboriginal right: The aborigines are also entitled to live within areas declared as Malay Reservations, forest and game reserves subject to conditions prescribed by the state authority. This provision prevails over the other legislation providing for reservations. However, it is also stated that the state authority may require them to leave the area with payment of compensation. ${ }^{134}$ Further information on the compensation is in the next section.

Fifth, compensation: Compensation is an indication of recognition by the states of the entitlement of the people to their land and resources. Under the Act, compensation for land is payable:

a. on the state's ordering the aborigines to leave the land declared as a Malay Reservation, forest reserve or game reserve (S 10(1));

${ }^{130}$ In Selangor for instance, within 10 years from 1990, almost $80 \%$ of the areas gazetted either as aboriginal areas or reserves, were revoked. The areas which were approved for gazetting in 1990 had yet to be gazetted as at 2001. Nicholas, above $\mathrm{n}, 33-4$.

${ }^{131}$ Aboriginal Peoples Act 1954 (Malaysia), s 8. It provides: '(1) The State Authority may grant rights of occupancy of any land not being alienated land or land leased for any purpose within any aboriginal area or aboriginal reserve. (2) Rights of occupancy may be granted (a) to (i) any individual aborigine; (ii) members of any family of aborigines; or (iii) members of any aboriginal community; $(b)$ free of rent or subject to such rents as may be imposed in the grant; and $(c)$ subject to such conditions as may be imposed by the grant, and shall be deemed not to confer on any person any better title than that of a tenant at will. (3) Nothing in this section shall preclude the alienation or grant or lease of any land to any aborigine.'

${ }^{132}$ See, eg, Rusaslina Idrus, 'The Discourse of Protection and the Orang Asli in Malaysia' (2011) 29(Suppl. 1) Malaysian Studies 53, 64; Colin Nicholas, Orang Asli: Rights, Problems, Solutions (Suhakam, 2010), 8.

${ }^{133}$ Aboriginal Peoples Act 1954, s 6(2)(iii),(iv).

${ }^{134}$ Ibid, s 10 (3):

The State Authority may be [sic] order require any aboriginal community to leave and remain out of any such area and may in the order make such consequential provisions, including the payment of compensation, as may be necessary. (4) Any compensation payable under subsection (3) may be paid in accordance with section 12. 
Izawati Wook, 'The Aboriginal Peoples Act 1954 and the Recognition of Orang Asli Land Rights', ISSN 2229984X', UUMJLS, vol. 6, no. 1, 2015, pp. 063-083.

b. on revocation of aboriginal areas or reserves (s 12(1)).

In these situations, the manner of the payment of the compensation for the land is according to $s 12$ - that is, to the aboriginal persons entitled or to the Director General to be held in trust for the persons or communities. ${ }^{135}$

Section 12 uses the word 'may' for requiring payment of compensation, indicating the discretion of the state authority on such payments. However, it was held in Sagong (No 2) that the word 'may' is to be read as 'shall' to avoid inconsistency with the constitutional provision protecting property rights. ${ }^{136}$

Another provision requires compensation for fruit or rubber trees planted by the aborigines on disposal of the land by the state authority (s 11(1)). Section 11(1) provides for compensation for fruit or rubber trees found on state land which is alienated or granted to others.

However, in practice, payment of compensation has been not for the land itself, especially before Sagong (No $2){ }^{137}$ but for dwelling and trees only. It is often stated that the compensation is not for the land, as the land was erroneously believed to belong to the states, but for the consequential damages - the buildings and trees that were lost. ${ }^{138}$ On the other hand, the text of ss 10 and 12 clearly requires compensation for the land. Only s 11 requires compensation upon alienation for fruit and rubber trees planted by the aborigines on state land.

Sixth, the exercise of the powers of the Federal Government and state as the protectors of the interests of the Orang Asli, and the protection that the law extended to these interests, require that any actions that affect these interests, that is, the excision of the reservations and orders to leave the reserved lands, must be taken with consideration of these interests as the first priority. In many situations, the interests of the Orang Asli to access resources can co-exist with the other interests in reservations, such as with forest and wildlife reserves as well as other environmental conservation-related reservations. However, frequently the interests of the Orang Asli have not been given adequate consideration.

\section{Specific Statement Of Policy On Orang Asli}

Consistent with the objective of the APA to protect the Orang Asli land, statements of policy relating to the administration of Orang Asli also acknowledge that the Orang Asli are entitled to their land.

A statement of policy in $1961^{139}$ contains important broad principles and 'special measures' to be adopted 'for the protection of the institutions, customs, mode of life, person, property and labour of the Orang Asli'. ${ }^{140}$ In particular, the statement reinforces the moral and legal rights of the communities to their customary lands and their autonomy in having a political identity of their own.

135 Ibid, s 12:

If any land is excised from any aboriginal area or aboriginal reserve or if any land in any aboriginal area is alienated, granted, leased for any purpose or otherwise disposed of, or if any right or privilege in any aboriginal area or aboriginal reserve granted to any aborigine or aboriginal community is revoked wholly or in part, the State Authority may grant compensation therefor and may pay such compensation to the persons entitled in his opinion thereto or may, if he thinks fit, pay the same to the Director General to be held by him as a common fund for such persons or for such aboriginal community as shall be directed, and to be administered in such manner as may be prescribed by the Minister.

136 Sagong (No 2) [2005] 6 MLJ 289, [41].

137 [2005] 6 MLJ 289.

${ }^{138}$ See eg, Nicholas, above n 132, 6.

139 Department of Information, 'Statement of policy regarding the administration of the aborigines of the Federation of Malaya' (Ministry of the Interior, 1961). As of 2001, the Statement was confirmed to be still in force by a Director-General of the JHEOA during testimony under oath during the Sagong Tasi land rights case.

${ }^{140}$ Some relevant paragraphs are listed down:

Para (a): The aborigines, being one of the ethnic minorities of the Federation, must be allowed to benefit on an equal footing from the rights and opportunities which the law grants to the other communities ... Para (c): The aborigines shall be allowed to retain their own customs, political system, laws, and institutions when they are not incompatible with the national legal system. Para (d): The special position in respect to land usage and land rights shall be recognized ... Also, the Orang Asli will not be moved from their traditional areas without their consent. 
Izawati Wook, 'The Aboriginal Peoples Act 1954 and the Recognition of Orang Asli Land Rights', ISSN 2229984X', UUMJLS, vol. 6, no. 1, 2015, pp. 063-083.

The 1961 policy statement reiterates an earlier statement issued in $1957 .{ }^{141}$ The 1957 statement aimed to correct the view that the Orang Asli did not have rightful territorial claims over their hereditary land because they were dependants of the government and inferior people. This had resulted in people being dispossessed and driven further inland. ${ }^{142}$ The policy states that the aborigines' way of life, customs, traditions and mode of life should be accepted and recognized. The hereditary land rights of the various local groups should be recognized by the states and they should not be forced to move against their will for any economic or political reason.

\section{Criticism of The Act}

Akhtar Tahir $\mathbf{J}$ in a recent Orang Asli claim for judicial review against alienation of their customary land stated that

the fact that the Act was enacted at all is a testimony that the rights of aborigine over the land occupied has [sic] been given due recognition. ${ }^{143}$

Nevertheless, despite the idea of protection, after almost 60 years in force, the APA is often seen as repressive against the communities that it appears intended to protect. Many allege that the APA in practice has been a disadvantage to the communities. ${ }^{144}$ Idrus, for instance, observes that as the Act sets up the Orang Asli as wards of the state, it essentially limits their rights as full citizens of Malaysia. ${ }^{145}$ The government agency created to assist the Director General is also frequently criticised for failure to represent the interests of the communities. One critique suggests that the Department functions more as an administrative arm of the executive government rather than as an independent representative organ representing Orang Asli interests. ${ }^{146}$

\section{The APA Vis-A-Vis The Laws And Policies On Forestry, Wildlife And Protected Areas}

In Peninsular Malaysia, areas of land, forestry, wildlife and protected areas are governed by various statutes including the National Forestry Act 1984 (NFA), the National Land Code 1965 (NLC), the National Park Act 1980 (NPA) and the Malay reservation enactments. Many of these statutes provide for reservation of land for different purposes including environmental conservation and for the protection of the Malays. In relation to reservation provided by these laws, the APA expressly provides that the Orang Asli may continue to live within the reservation regardless of the contrary provisions within the relevant legislation.

In territories established as National Park and protected areas, there is no restriction on the rights of the Orang Asli to access land under the relevant legislation. ${ }^{147}$ Some suggest that the legislation restricts their rights to own and control their traditional lands within the territories. ${ }^{148}$

${ }^{141}$ The Long Term Administration of the Aborigines of Malaya 27 May 1957 ANM - 2005/0018322 (Malaysia National Archive).

${ }^{142}$ Ibid, [11(31)].

143 Mohamad Nohing [2013] MLJU 291, [12].

144 There are many writings that criticise the APA. See, eg, Idrus, above n 100; Nicholas, above n 127; Hakimah Yaacob, 'Human Rights of Orang Asli in Peninsular Malaysia - Paper presented for United Nations Delegates on Minority ' (SUHAKAM - Human Rights Commission Malaysia, 2008); Dentan, Robert Knox et al, Malaysia and the Original People: A Case Study of the Impact of Development on Indigenous Peoples (Allyn and Bacon, 1997), 70; Hasan Mat Nor et al, 'Mengapa kami jadi begini? Konflik masyarakat Orang Seletar dan Pembangunan Iskandar, Johor Bahru, Malaysia (Why do we become like this? The conflict of Orang Seletar communities and Iskandar Development, Johor Bahru Malaysia)' (2009) 5(2) Malaysian Journal of Society and Space 1, 23-4; Colin Nicholas and A Baer, 'Health care for the Orang Asli: Consequences of paternalism and non-recognition' in H L Chee and S Barraclough (eds), Health care in Malaysia: The dynamic of provision, financing and access (Routledge, 2007) 119, 120, Tuck-Po, Lye, Changing Pathways: Forest Degradation and the Batek of Pahang, Malaysia (Strategic Information Research Development, 2005); Geoffrey Benjamin, 'On Being Tribal in the Malay World' in Geoffrey Benjamin and Cynthia Chou (eds), Tribal Communities in the Malay World: Historical, Cultural and Social Perspectives (Institute of Southeast Asian Studies, 2002) .

${ }^{145}$ Idrus, above $\mathrm{n} 100,54,65$.

${ }^{146}$ Cheah Wui Ling, 'Sagong Tasi: Reconciling State Development and Orang Asli Rights in Malaysian Courts' (National University of Singapore and Asia Research Institute, 2004), [2.1.2]

${ }^{147}$ Eg of the legislations: National Parks Act 1980 (Malaysia); Protection of Wild Life Act 1974 (Malaysia); Wild Life Conservation Act 2010 (Malaysia).

${ }^{148}$ Nicholas, above n 127; Yaacob, above n 144, 25. 
Izawati Wook, 'The Aboriginal Peoples Act 1954 and the Recognition of Orang Asli Land Rights', ISSN 2229984X', UUMJLS, vol. 6, no. 1, 2015, pp. 063-083.

In relation to land governance, although the sovereign ownership of the land lies with the State Authorities, it is expressly provided in the National Land Code that its provisions do not override the rights and interests in land acquired under customary law. ${ }^{149}$

Specifically, the interest of the Orang Asli in forest resources is recognized in two statutes: the National Forestry Act 1984 (NFA) and the Wild Life Conservation Act 2010 (WLCA). ${ }^{150}$ In the NFA, a specific provision gives power to a state authority to exempt the Orang Asli from license requirements or payment of royalties for taking forest produce from state land or alienated land for certain purposes specified, mainly for their personal use. ${ }^{151}$ The forest produces other than the wild life are subject to the NFA and the forestry legislation of states.

The WLCA allows the Orang Asli to hunt 10 specified animals otherwise protected for sustenance only so that they may not be sold. ${ }^{152}$ Sale of the animals is prohibited which is an offence punishable under the Act. ${ }^{153}$ This newly enacted legislation reduces the privilege accorded in the former Act, the Protection of Wild Life Act 1974, which allowed the Orang Asli to kill or take any wild animals and birds for food. ${ }^{154}$ This is another subject of resentment among the Orang Asli. Some suggest that the provision is 'too-prescriptive' and 'restrictive'. ${ }^{155}$ It does not take into account the situation on the ground. ${ }^{156}$

\section{Conclusion}

In conclusion, there is a strong indication to argue that the laws aim to protect the land rights of the Orang Asli. Overview of the historical development of law and policy in Malaysia suggests that the present laws in Malaysia, both statutory and the common law are directly influenced by the long standing practice and principles that recognize and respect for the autonomy and regard for the existing rights of people. These principles laid the groundwork for the present laws regulating land and forests in Malaysia that influence its meaning and interpretation.

Situated within its historical context, the longstanding practice and historical development of the laws, particularly colonization practice and the introduction of laws, developed into principle of respect to the rights of the existing inhabitants. This established principle holds that the laws acknowledge the existing rights and

${ }^{149}$ National Land Code (Malaysia), s 4.

150 The Act came into force on 26 December 2010.

${ }^{151}$ National Forestry Act 1984 (Malaysia), s 62(2)(b):

Subject to any contrary direction by the State Authority, the Director may reduce, commute or waive any royalty in respect of, or exempt from royalty, (b) any forest produce or class of forest produce taken from any State land or alienated land by any aborigine for: (i) the construction and repair of temporary huts on any land lawfully occupied by such aborigine; (ii) the maintenance of his fishing stakes and landing places; (iii) fuel wood or other domestic purposes; or (iv) the construction or maintenance of any work for the common benefit of the aborigines.

S 40(3) allows State Authority to exempt the requirement of removal license for taking forest produces by the aborigines in alienated land on the same purposes specified in s 62(2)(b).

152 Wild Life Conservation Act 2010 (Malaysia), s 51(1):

Notwithstanding anything in this Act, an aborigine may hunt any protected wildlife as specified in the Sixth Schedule for his sustenanceor the sustenance of his family members.

The list of wildlife is specified in the Sixth Schedule. They are wild pig, sambar deer, lesser mouse deer, pig tailed macaque, silvered leaf monkey, dusky leaf monkey, malayan porcupine, brushtailed porcupine, white breated waterhen, emerald dove. ${ }^{153}$ Ibid S 51(2)-(3):

(2) Any protected wildlife hunted under subsection (1) shall not be sold or exchanged for food, monetary gains or any other thing. (3) Any aborigine who contravenes this section commits an offence and shall, on conviction, be liable to a fine not exceeding ten thousand ringgit or to imprisonment for a term not exceeding six months or to both.

${ }^{154}$ Protection of Wild Life Act 1974 (Malaysia), s 52.

${ }^{155}$ Interview data: a lawyer representing Orang Asli and the Director of the Center of Orang Asli Concern.

156 Some suggest that some items listed are not even used to be taken by the people. Interview data: Orang Asli representatives, a lawyer and a researcher. 
Izawati Wook, 'The Aboriginal Peoples Act 1954 and the Recognition of Orang Asli Land Rights', ISSN 2229984X', UUMJLS, vol. 6, no. 1, 2015, pp. 063-083.

interests that derive from the custom and usage of the people. The laws could not be taken to override these interests unless specifically stated so.

On the principle of equality, which is also the basic principle of law, the principle of respect to the rights of people is not only applicable to the Malays, but also the Orang Asli who are known to be the first people of the peninsula.

Further, examination of the laws affecting the Orang Asli and their access to land and resources suggests that there is substantial recognition of the interests of the Orang Asli as the indigenous minorities under the law although the realization of it is hampered by various loopholes in the law and other prevailing factors. The law is paternalistic as it was predominantly based on the prevalent perception towards the aboriginal peoples who were considered low in the perceived social scale. But the main objective is to protect the people who it perceived as unable to protect their own interests. From this perception, and affected by various prevailing economic, political and social interests, the APA did establish a framework to protect the land rights of the Orang Asli. In fact it acknowledges the existence of the interests that belong to the communities. It also acknowledges the need to protect the interests. It posits the state authorities as the protector of these rights and interests and subject to the duty under the Act. It has not been the case that the land of the communities belongs to the State but the State's interests are subject to these existing interests.

From the position of the Federal Government and the state authorities as the protectors of the interests of the Orang Asli, and the regards that the laws have for these interests, it is contended that the actions that affect these interests, ie excision of the reservations and order to leave the reserved lands must be exercised with great care with consideration of these interests as the first priority. In many situations the interests of the Orang Asli to access resources can co-exist with the other interests in reservations such as the forests and wildlife reserves as well as other environmental conservation related reservations. However, often the interests of the Orang Asli have not been given adequate concern.

This paper suggests that this historical overview provides the theoretical underpinning that underlies the law and its future direction in relation to the access and proprietary rights of the indigenous minority to the resources. The principle that developed from it, that is respect to the rights of the existing inhabitants, also shapes the development of the laws relating to land and other resources in Malaysia although it has been gradually restricted. 